experience has shown that ploughing is preferable to surface harrowing, and that seed-bed consolidation is essential for success. The suitability of mixtures for re-seeding, and the chemical aspect of grassland improvement are also considered. An article on ensilage and grass drying completes the other side of the picture, the different methods of conserving grass and their relative feeding values being fully described and discussed. Among other subjects of current interest in this number of the Journal is a well-illustrated account of a new method of trapping and destroying rabbits on a large scale. The Journal is now to be issued half-yearly instead of quarterly.

\section{Vocational Training and Black Rust Control}

Tre classical struggle of the United States Department of Agriculture against the black rust disease (Puccinia graminis) of small grains, forms the subject of a leaflet (No. 1, Revised 1939) entitled "Teaching the Control of Black Stem Rust of Small Grains in Vocational Agriculture Classes". This has been prepared by the Vocational Division of the Office of Education, U.S. Department of the Interior. Destruction of common barberry, the alternative host plant of the fungus, still requires to be practised, and a teaching plan for the portrayal of this need is detailed in the leaflet. The life-history of the fungus and its devastating effects are shown by effective diagrams and small photographs, and even the most unimaginative teacher could scarcely fail to thrill a class if he followed the suggestions put forward. Co-operation with the U.S. Department of Agriculture has been closely maintained, with the result that a valuable source of specialist information is provided for the general teacher.

\section{Animal Husbandry in India}

The report has just been published of the Proceedings of the third meeting of the Animal Husbandry Wing of the Board of Agriculture and Animal Husbandry in India (Simla : Gov. India Press, 1940). The meeting was held at New Delhi during February $20-23,1939$, and the variety of the nineteen topies discussed indicates the complexity of India's problems and the research activities which have been stimulated through the influence of the Imperial Council of Agricultural Research. Reference to the Proceedings and the discussions recorded there show how valuable to the investigators and agriculturists concerned must be the pooling of information from all the corners of the land which takes place at such meetings and helps to determine the lines upon which particular investigations must be conducted. But we must add that the form in which the Proceedings are published leaves much to be desired: there is no index to the subjects or authors mentioned in these 307 pages, and even the list of topics has no page references to guide the inquirer; so that, for example, we find the discussion on the warble-fly on p. 88, and the introductory remarks on which the discussion was based on p. 155, with a title which, as printed, is unintelligible.

\section{Pictorial Illustration for Engineering Draughtsmen}

In the drawing office a rigidly conventional system of orthographic projection is employed which tends towards the suppression of ability in pictorial representation. To the draughtsman himself his conventional views are sufficiently expressive and communicative, but occasions arise when greater realism is necessary in order to inform and impress the uninitiated. For guidance in this unaccustomed field, the Association of Engineering and Shipbuilding Draughtsmen has issued a new publication entitled "Freehand Drawing and Pictorial Illustration for Draughtsmen" by W. H. Kerry and E. W. Stott (London: The Draughtsman Publishing Co., Ltd. 2s.) which shows how in a number of typical cases pictorial sketches can be prepared. A chapter devoted to "Perspective Construction", on which the subsequent treatment is based, is followed by a statement of the nature and classes of work which the engineering draughtsman may be called upon to treat pictorially, and the purposes for which this method of treatment is necessary ; as, for example, the illustrations required by the Patent Office. The main subjects are dealt with under the titles "Treatment of Machine Details", "Conventional Treatment" and "Illustration for Reproduction with an Outline of some of the Printing Processes", and the whole forms a sequence of practical instruction which must prove invaluable to the draughtsman who is unskilled in this unfamiliar field and uninformed regarding the methods to use for different conditions of reproduction.

\section{Properties and Applications of Witherite}

IN Engineering of September 13 there is an interesting article on the properties and applications of witherite (barium carbonate). It is stated in a handbook issued jointly by the Holmside and South Moor Collieries, Ltd., and the South Moor Collieries, and the Settlingstones Mines, Ltd., that witherite is found in economic quantities only in the northern part of England and that the mines producing it supply the world demands for the mineral. The material derives its name from that of Dr. W. Withering, a Birmingham physician and amateur geologist, who in 1784 when examining samples taken from an old lead mine at Alston Moor, on the borders of Cumberland and Northumberland, first recognized the mineral to be chemically distinct from barytes.

Large quantities of witherite are used annually in the preparation of precipitated barium sulphate (permanent white) which is employed in the paper industry for the manufacture of highly glazed coated papers. It is also used in the printing ink and colour industries, in the manufacture of paints and as a filler in the rubber, linoleum and other industries. Among other engineering applications of witherite is the softening of water for boiler feed. It is specially useful when scale-forming and corrosive waters are encountered. Thus sodium and calcium sulphates are converted into the carbonates of these metals, with the precipitation of insoluble barium sulphate. Ground witherite mixed with wood charcoal, usually 
in the proportion of $\mathbf{4 0}$ per cent of the former and 80 per cent of the latter, has. been used for many years as an energizer for carburizing compounds in the case-hardening industry. Considerable proportions of barium oxide, in some cases nearly 50 per cent by weight, enter into the composition of crown and flint optical glasses used for the production of lenses. Finely divided barium carbonate is also claimed to increase the resistance of cement to the action of sulphate-containing waters.

\section{Credit and the Family Budget}

The Office of Education, United States Department of the Interior, has issued a bulletin "Credit Problems of Families" (Vocational Division Bulletin No. 206, Home Economic Series No. 23) to aid teachers of home economics in guiding students in an understanding of the place of credit in family financial management and in the solution of their own credit problems. Credit has played an increasing part in recent years in the financial plans of American families, and this study, which covers both credit for everyday use and long-term uses of credit, is intended to assist the understanding of the principles governing the sound use of credit. Numerous suggestions to teachers are included.

\section{Help for Scientific Research in Canada}

THE Canadian Government has announced the appointment of nine members to administer funds presented by patriotic citizens for assisting technical projects and scientific investigations now being undertaken or proposed by the National Research Council with the object of increasing the efficiency of the Canadian war effort. The chairman is Dean C. J. Mackenzie (acting president of the National Research Council), and the members include Sir Frederick Banting, Mr. J. S. Duncan (Deputy Minister for Air), Prof. Maas (head of the Physics Department of MeGill University), and Colonel Allen Magee (executive assistant to the Minister of National Defence). Funds given or promised amount to $£ 225,000$.

\section{The Sedov on a New Expedition}

THE Geographical Department of the Northern Sea Route Administration (U.S.S.R.) has sent out the icebreaker Sedov on a new expedition to the northeastern part of the Kara Sea. It will be remembered that the Sedov returned to Murmansk on January 29, 1940 , after a remarkable drift in the Arctic of twentyseven months duration. The head of the new expedition is Mr. V. I. Vorobyev. The purpose of the expedition is to study one of the most important parts of the Northern Sea Route in the Kara Seafrom Izvestia Tsik Islands to Russky Island. The total length of this part is about two hundred nautical miles. The expedition is to carry out hydrographic and hydrological research : it will make systematic soundings of the depths of the sea, study the currents, wind regime, ice conditions, and carry out magnetic observations.

\section{Announcements}

DR. K. E. BuLLEN, lecturer in mathematics at University College, Auckland, New Zealand, known for his work in seismology, has taken up an appointment in the Department of Mathematics of the University of Melbourne.

SIr Arthur Hurst will deliver the eighteenth Norman Kerr Lecture to the Society for the Study of Inebriety on October 8 at 4 p.m. in the Friends House, Euston Road. His subject will be "Alcohol and the Organs of Digestion".

IN consequence of the War, it has been decided to postpone, for the present, the Chadwick Public Lectures which were to have been delivered this autumn.

THe following are serving as officers of the Society of Chemical Industry for 1940-41 : President, Prof. J. C. Philip ; Honorary Treasurer, Dr. L. H. Lampitt; Honorary Foreign (or Overseas) Secretary, Dr. Wm. Cullen; Chairman, Bureau of Chemical Abstracts, Dr. L. H. Lampitt; General Secretary, H. J. Pooley, Clifton House, Euston Road, London, N.W.1.

THe average mortality rate from all causes in the large cities of the United States for the four weeks ended June 15, based on data received from the Bureau of the Census, was 10.9 per thousand inhabitants. The average rate for this period in the five preceding years was $11 \cdot 0$.

The Medical Research Council has received four motor-vehicles specially equipped for medical work from the United States. These were originally pur. chased by the American Quakers and the International Commission for the Assistance of Child Refugees for use in France. The vehicles now are to be used principally in the work of the Emergency Blood Supply depots in the neighbourhood of London.

Dr. F. Hoyle, St. John's College, Cambridge, writes: "I have noticed an error in a letter by Lyttleton and myself on 'The Evolution of the Stars' appearing in NATURE of July.20, p. 97. The sentence 'Thus the effect of collisions is to excite the vibrational and rotational levels of the ${ }^{3} \Sigma$ state of the molecules, and this internal energy can be radiated by quadrupole transitions to the ground state of the molecules', should read : 'Thus the effect of collisions is to excite the vibrational and rotational levels of the $1^{1} \Sigma$ state of the molecules, and this energy can be radiated by quadrupole transitions as an infra-red spectrum'."

Erratum. In the obituary of Prof. A. E. H. Love in Nature of September 21, p. 393, three lines from foot of second column, for "Anthony Berry" read "Arthur Berry". 